\title{
RIGHT TO EDUCATION AS A FACTOR OF EDUCATION PUBLIC ADMINISTRATION IN THE EUROPEAN COURT OF HUMAN RIGHTS PRACTICE
}

\author{
Andrii M. Aparov ${ }^{1}$ \\ Olena M. Ivanii ${ }^{2}$ \\ Roman M. Shestopalov ${ }^{3}$ \\ Liudmila I. Adashys ${ }^{4}$ \\ Oleg V. Morozov ${ }^{5}$
}

\begin{abstract}
The relevance of the issue under study is stipulated by the importance of compliance of the education public administration with the right to education in modern conditions. purpose of the article is to elucidate the right to education as a phenomenon that determines the direction and limits of public administration in the educational sphere. A leading research approach is the systematic analysis of the right to education as a factor in the content and nature of public administration in the educational field. The empirical basis of the study is the European Court of Human Rights practice in the field of the right to education. The article identifies
\end{abstract} and describes six provisions that characterize the right to education and determine the direction and limits of public administration of education: the obligation of the state to guarantee access to education institutions for persons under the jurisdiction of the state; the state has the discretion to determine the content of education and spread certain philosophical and world outlook ideas through the education. the state is obliged to provide free of charge elementary and general education; the obligation of the state is to ensure equal access of persons to education; the obligation of the state is to develop the school system; to establish the optimal

\footnotetext{
${ }^{1}$ Sumy State Pedagogical University named after A.S. Makarenko, Romenskaya Str. 87, Sumy, 40002, Ukraine. E-mail: aparov26@uohk.com.cn

Sumy State Pedagogical University named after A.S. Makarenko, Romenskaya Str. 87, Sumy, 40002, ${ }^{2}$ Ukraine

Sumy State Pedagogical University named after A.S. Makarenko, Romenskaya Str. 87, Sumy, 40002, ${ }^{3}$

Ukraine

University of Customs and Finance, Volodymyr Vernadsky Str. 2/4, Dnipro, 49000, Ukraine ${ }^{4}$

University of Customs and Finance, Volodymyr Vernadsky Str. 2/4, Dnipro, 49000, Ukraine ${ }^{5}$
} 
system of scholarships; recognition of a certain degree of autonomy to educational institutions. The material in this article may be useful for scholars exploring the right to education and public administration of education. The main provisions of the study can be used to improve public administration of education, monitor the quality of education, and improve educational legislation.

Keywords: free development, state duty, educational sphere, process of learning.

\section{Introduction}

In modern conditions of society development, proceeding, from the principle of tolerance and nondiscrimination, and equality, free development of a human being, ensuring his comprehensive development, which determines the relevance of the right to education, is crucial. It is the implementation of the right to education that allows a person to be an active participant in public relations, to realize his abilities, and to develop them. The right to education, as well as social and economic rights in general, is often regarded as a means of accessing a person to certain needs that are necessary for a dignified life or as a means of overcoming social differences between different social strata of the population (Mbajiorgu and Mafumo, 2014). "Education takes on the status of a human right because it is integral to and enhances human dignity through its fruits of knowledge, wisdom and understanding. ...Education is the very prerequisite for the individual to function fully as a human being in modern society" (Claude, 2005).

As it is well-known, human rights are addressed to a state that is committed with both negative and positive obligations to respect, protect and safeguard human rights. The right to education, by its very nature, requires the state to fulfill a large part of its positive obligations, in particular with regard to the establishment and maintenance of the educational establishments system. Which, in turn, necessitates the organization of effective management of the education field. It should be noted that in the context of a complex structured society, in the conditions of a developed civil society and the implementation of the rule of law principle, the issue of public 
administration in general and the educational sector administration in particular, becomes relevant. Particularly important is this issue for the post-soviet states, where for quite a long time operated an administrative and command system with its centralism and bureaucracy, which did not recognize human rights as a benchmark for public policy. Axiological principles of public administration changing necessitates a rethinking of approaches to the organization of administration itself (Pysmennyi and Lypovska, 2015), especially in the context of globalization (Hou et al., 2010).

The issue of the right to education providing by the state and, in particular, of the administration of the educational sphere, is in the focus of scholars. M. Manan (2015) examined the implementation of the right to education in Indonesia. Globalization-induced changes in higher education management in Ukraine became the subject of analysis of the team of authors Markina et al. (2019), G. Mbajiorgu and T. Mafumo (2014) researched the implementation of the right to education in South Africa, and problems of Public Administration of Legal Education in the Practice of the European Court of
Human Rights has not been left beyond the scientists' attention (Karahioz et al., 2019). However, the issue of the right to education as a factor in the content and the essence of public administration in the educational sphere through the lens of the European Court of Human Rights Practice has not been the subject of scholars' analysis.

The purpose of this article is to elucidate the right to education as a phenomenon that determines the focus of public administration on the educational sphere and is a "red line" for public administration.

\section{Research Mehodology}

A key approach used in this article is a systematic analysis of the right to education as a factor in the content and the essence of public administration in the educational field. The research is based on the understanding of the right to education as a kind of human rights, which are interpreted as universal, inalienable, natural and fundamental possibilities inherent in a person.

The specifics of the right to education, which is characterized by a binary nature: on the one hand, the right to education is a natural right that 
ensures the free development of the individual, the possibility of developing potential opportunities, especially in the information society, and on the other hand, social and economic nature inherent in this right makes it directly dependent on the state of economic development of the state (given the mostly positive nature of the state's obligations in the field of education). Which led to the need to focus on the study of the right to education, based on the provisions of the European legal culture. Within the American legal system, economic rights are not seen as a form of human rights. That is why the United States did not join the International Covenant on Economic, Social and Cultural Rights (1966).

The use of the provisions of the natural understanding of law, rather than normative, is also due to the fact that within the first the main emphasis is on the person and his individual interests, which provides for the autonomy of the person (both physical and legal). And this requires the state to take into account the principle of autonomy, in particular, the autonomy of educational institutions, the principle of equality of persons before the law and equal access to educational institutions. Which is not typical of a society which legal system is based on the provisions of the normative understanding of law, law is identified with the law, individual will is excluded, as well as social activities of an individual (herewith the purpose of educational institutions is to promote the will of public authorities, and public administration comes to exact execution of this will).

The study Right to Education as a Factor of Education Public Administration in the European Court of Human Rights Practice is based on an understanding of the implicit nature of human rights. The texts of legal acts, including international ones, contain concise wording about the existence of a person's relevant right, and the content of these rights is revealed in time, in particular, through the practice of subjects of law enforcement, which determined the empirical basis of this paper. In addition, the implicit nature of human rights necessitates a dynamic interpretation of the rules of law contained in legal acts.

The Practice of the European Court of Human Rights has been empirically based on proceeding from the fact that the institution operates within the Council of Europe, 
comprising 47 Member States; accordingly, the composition of the European Court of Human Rights includes 47 judges. This allows us to find out a general approach to understanding the essence and content of the right to education. However, it is clear that states have wide discretion as to the means and ways of exercising this right (herewith this discretion also allows for an analysis of the European Court of Human Rights Practice).

The study of the practice of the European Court of Human Rights was carried out using logical methods of analysis and synthesis. The decisions of the European Court of Human Rights in cases against Belgium, Denmark, Germany, Greece, Italy, Norway, Sweden, Turkey, United Kingdom were analyzed. The hermeneutic method was set as a principle of the study. The hermeneutic method allowed us to take into account the autonomy of interpretation of the provisions of the Convention for the Protection of Human Rights and Fundamental Freedoms (1950) and the Protocol to the Convention for the Protection of Human Rights and Fundamental Freedoms (1952), which is important in the context of this study. The autonomy of interpretation of certain terms of these documents allows not to focus on their different understandings in the member states of the Council of Europe, but to clarify the common vision within the Council of Europe, to determine the presence or absence of consensus on the phenomenon under study.

In addition, it is the hermeneutic method that allowed to take into account the dynamic interpretation of the Convention for the Protection of Human Rights and Fundamental Freedoms (1950) by the European Court of Human Rights, as the application of hermeneutics in law involves taking into account not only text but also social context. Logical methods of analysis and synthesis, as well as the hermeneutic method were used in the elaboration of the texts of the Universal Declaration of Human Rights (1948) and the International Covenant on Economic, Social and Cultural Rights (1966).

\section{Results and Discussion}

The right to education is an important factor in the free development of a human being, ensuring his or her full development in the current conditions of society development. The right to education is not absolute and imposes 
negative and positive obligations upon the state. One of the positive obligations is the necessity to adopt educational legislation. The right to education implementation necessitates the public administration of education.

At the same time, the right to education determines the content of public administration of education, defines its boundaries. The analysis of international treaties in the field of education and the Practice of the European Court of Human Rights allows us to distinguish the following provisions, which are the factors of public administration of education.

1.

The State shall guarantee access to existing educational institutions within the State and the official recognition of the training completed to persons under its jurisdiction. This obligation does not impose on the State excessive obligations to create and fund institutions that will provide any type of education.

2. The state has the discretion to determine the content of education, dissemination through education of certain philosophical and world outlook ideas. The state is obliged to provide education and training that is consistent with the religious and philosophical beliefs of the parents. The state is obliged to provide the person with objective and critical information in the process of learning, taking into account the pluralism of approaches.

3. Primary and general education shall be free of charge. Primary education should be compulsory. The fulfillment of these duties' rests with the state. The state cannot shift the obligation to guarantee the right to education to private educational institutions.

4. The state should guarantee equal access to education for persons. Discrimination is interpreted as a different treatment, without objective and reasonable justification, to persons in similar situations.

5. The state should develop the school system; establish an optimal system of scholarships, and teachers' remuneration. An inclusive education is an important means of ensuring equality of people and 
promoting the development of each person.

6. The state should guarantee certain degree of autonomy to educational institutions.

The right to education is universal. It is enshrined in a number of international declarations, covenants that are part of both "soft law" and "hard law". It is long since the Universal Declaration of Human Rights (1948) proclaims the human right to education. It should be noted that the preamble to the Universal Declaration of Human Rights (1948) states that it is education that is a means of promoting respect for human rights. Given that the Universal Declaration of Human Rights is a soft law, the International Covenant on Economic, Social and Cultural Rights (1966) was adopted in 1966, Art. 13 of which, enshrines the human right to education and determines the basic obligations of states as to this right implementation. An important international treaty on the protection of the right to education is the Convention for the Protection of Human Rights and Fundamental Freedoms (1950), which provides for the functioning of the
244 European Court of Human Rights, protecting, in particular, the right to education, enshrined in Art. 2. of the First Protocol to the Convention for the Protection of Human Rights and Fundamental Freedoms (1952).

Considering the autonomy of interpretation of the provisions and concepts of the Convention for the Protection of Human Rights and Fundamental Freedoms by the European Court of Human Rights, it should be noted that the concept "education" is understood by the European Court of Human Rights (1982) as "the education of children is the whole process whereby, in any society, adults endeavor to transmit their beliefs, culture and other values to the young". In doing so, the European Court of Human Rights (1982) differentiates education from other related concepts "teaching or instruction refers in particular to the transmission of knowledge and to intellectual development". It is from this understanding of education that we proceed in this study.

It should be noted that Art. 2 of the First Protocol to the Convention for the Protection of Human Rights and Fundamental Freedoms is applied not only to school education (European 
Court..., 1996) but also to higher education (European Court..., 2006a), which is a means of enhancing human knowledge and possesses cultural and scientific value for a human being and society in general as well (European Court..., 2006b). The analysis of international treaties in the field of ensuring the right to education, the European Court of Human Rights Practice allow to distinguish the following provisions, determining the boundaries and focus of public administration in the educational sphere.

1. The right to education imposes on the State positive obligations to ensure the persons within the jurisdiction of StatesParties to the Convention for the Protection of Human Rights and Fundamental Freedoms, to use the means of education existing in the States and to officially recognize the completed training (European Court..., 1968). This obligation does not impose on the State excessive obligations to create and fund institutions that will provide any type of education. Convention for the Protection of Human Rights and Fundamental Freedoms does not impose on the state obligations as to specific level of the educational sphere financing. The issue of forming a state education system or providing subsidies to private schools is a matter of discretion for the state. At the same time, the right to education should be guaranteed both in public and private educational institutions (European Court..., 2005). The right to education is not absolute. The state may restrict the right to education if such restrictions are legally prescribed and legitimate. However, the existence of restrictions that violate the essence of the right to education will be interpreted as a violation of that right (European Court..., 1993). Existence of positive obligations regarding the adoption of legislation regulating the educational sphere, fixing the principles of educational institutions functioning, control over the educational institutions activities necessitates the public administration of the educational sphere.

2. The right to education provides for the state's ability to determine the content of education and does not prohibit it from spreading certain philosophical and world-view ideas through education. Moreover, teaching a large number of subjects is not possible without a certain philosophical basis (European Court..., 1976). Therefore, education is closely 
linked to a particular ideology. As it is known from history, Nazi, fascist and communist authorities have effectively used education to spread their own ideology among society. In this context, it is worth noting research of the team of authors, elucidating the importance of the world outlook on the perception of nature, society and a human being to shape the content of education (Bidjiev et al., 2017). The significance of the principle of tolerance in education is described by M. Moyaert (2018).

A. Kuchuk et al. (2019) quite clearly substantiated the differences in the ideological basis of legal education within the states where the positivist understanding of law prevails and within the states where the system of law is based on the natural understanding of law. The right to education obliges the state to provide education and training that is consistent with the religious and philosophical convictions of the parents. The cases related to religious issues (European Court..., 2011), the cases related to sexual bringing up (European Court..., 1976), the cases related to ethics compulsory studying (European Court..., 2009) are more and more often considered in the European Court of Human Rights.

However, education should have a different direction in modern society. In accordance with the Art. 26 of the Universal Declaration of Human Rights (1948), the purpose of education should be promoting universal development of the individuality, contributing to respect for human rights, tolerance, mutual understanding between peoples, and maintaining peace. And, according to Art. 13 of the International Covenant on Economic, Social and Cultural Rights (1966) "education should be directed towards the full development of the human person and the awareness of his or her dignity and should enhance respect for human rights and fundamental freedoms". The state is obliged to provide a person with objective and critical information in the process of learning, taking into account the pluralism of approaches. Otherwise, educators should be exempt from teaching based on religious or philosophical beliefs (European Court..., 2007).

3. The state is obliged to provide free elementary and general education. 
Herewith primary education should be compulsory. The state can enshrine in law the possibility of obtaining primary education in both public and private schools (European Court..., 2006). States have wide discretion in this matter, which also allows for the possibility of proper home education. However, the state cannot transfer the obligation to guarantee the right to education to private educational institutions (European Court..., 1995). In this context the case of Verein Gemeinsam Lernen (European Court..., 1995) is cognizable, which, in particular, raises the following issues. First, the availability of private schools can reduce the number of pupils in public schools to such a level that the state will be burdened with excessive funding for public schools. Second, shifting to the state the obligation of the educational services provision provided by church schools attended by a large number of persons could be an excessive burden for the state (the same applies to other schools, including private ones).

4. Public administration in the educational field should ensure equal access of people to education. Prohibition of discrimination provides for equal treatment of persons in appropriate circumstances, unless there is objective and reasonable justification (European Court..., 1991). The principle of objectivity makes it necessary to emphasize that in Concurring Opinion of the mentioned decision Judge Thor noted that "By their very nature they may cause inconvenience to certain people since equal treatment of all persons in similar situations may not only be impractical but also impossible" (European Court..., 1991). By regulating access to educational institutions, the state may provide quality assessments to select those who can successfully complete the training (European Court..., 2013).

All individuals should be guaranteed fair and equal access to education, including higher education. We emphasize that different treatment of persons will not be regarded as discrimination, provided that the legitimate aim is pursued and the proportionality of the restrictions is pursued as well. Herewith, Convention for the Protection of Human Rights and Fundamental Freedoms does not contain a list of "legitimate goals", so states have the discretion to legislate such goals. Also important is the ability of the 
individual to anticipate the possibility the right to education restricting. The discretion of States to regulate access to education for persons with disabilities is wide. States are in a better position than international judges in this matter. Since they have information about active powers within their jurisdiction, they are better aware of the local educational needs and situation in the use of educational resources. Although the state should be vigilant in choosing the means of access to education for persons with disabilities (European Court..., 2016). For example, refusing of a non-specialist school to accept a child with a severe mental retardation or severe hearing impairment or autism, refusing to build a lift at a school for use by a child with muscular dystrophy does not constitute a violation of the right to education.

However, refusal to accept the person who passed the entry competition in the Music Academy, if such refusal is based solely on the fact that the person is blind, without attempting to ascertain the needs of that person, to ascertain special facilities is an example of discrimination in access to education (European Court..., 2016). The deduction of persons for disciplinary violations, and violations of academic integrity are not considered as discrimination in access to education (European Court..., 2000).

5. The state should develop a school system; establish an optimal system of scholarships, and teachers' remuneration. This provision imposes on the State positive obligations for the implementation of which there must be adequate financial support. This problem is common to developed countries, for example, the United States. Thus, in Minnesota, systematic underfunding of schools causes student outflows to other states, dismissing teachers because of low pay (Education Minnesota, 2019). Public authorities should duly ensure the right to education (as well as the related rights) in their educational establishments or educational establishments authorized by them. It should be noted that the establishment of specialized educational institutions will facilitate the exercise of the right to education of persons with disabilities. In a modern society, inclusive education is a means of ensuring equality of people and promoting the development of each person. At the same time, it requires additional competences from teachers involved in the educational process with 
people with disabilities (Al-Shammari et al., 2019).

Thus, we can conclude that an important indicator of the effectiveness of public administration of education is to ensure the accessibility of pupils and students to educational institutions by providing the necessary conditions for the functioning and development of the system of educational institutions. This will allow to increase the number of additional places for pupils and students. We emphasize that, within the implementation of this task, the creation of economically advantageous conditions for the establishment and functioning of private schools, including higher schools, may occur.

\section{Public administration of the} educational sphere should be based on recognition of a certain degree of autonomy of educational institutions. The autonomy of educational institutions "is a key issue on the political agenda of many European countries. During the last twenty years, schools have been the subject of numerous reflections and reforms, particularly in the level of autonomy granted" (Iftene, 2014). It is autonomy that enables educational institutions to respond adequately and timely to the challenges of society, to carry out high-level scientific research, to provide an adequate level of educational services, and thus to fulfill their social function. In the international debate on centralization and decentralization of higher education management, there are more and more supporters of the autonomy of universities. Thus, the UK universities are fully autonomous in all aspects of administration. In the Netherlands, universities have broad competencies in all organizational, financial, staffing and academic matters (unlike universities in France which have almost no such authority) (Erçetin and Fındık, 2016).

The autonomy of educational institutions should not be a factor in the provision of poor-quality educational services. Given the autonomy of educational institutions, it is the duty of the state as to the right to education provision is to guarantee a certain level of competence of a graduate of an educational institution. This necessitates the establishment of educational standards. A unified approach within national states to the establishment and implementation of educational standards 
is a means of ensuring the proper level of knowledge, skills and competences of a person studying in educational institutions and receiving a certificate of completion of the course of studies (school leaving certificate, diploma, certificate, etc.). Individual states have introduced an independent assessment of the knowledge and competence of graduates of educational institutions and/or entrants to a higher education institution; monitoring the quality of education in order to ensure the appropriate level of competence of an educational institution graduate by the state. In Ukraine, creation of the support schools has also become an important means of improving the quality of education, which has helped to ensure equal access to quality education for children living in rural areas and attending low-fill schools where one teacher taught several subjects (Education in Ukraine..., 2018).

\section{Conclusions}

Thus, the right to education is a crucial factor in the free development of the individual, a means of implementation of his opportunities and active participation in modern society. The presence of positive and negative obligations of the state as to the right to education exercise, stipulates the necessity of education public administration. Thus, the right to education is a factor in the need for public administration of education and determines the essence of that administration.

The main provisions affecting the content of the education public administration are: the obligation of the state to guarantee access to education institutions for persons under the jurisdiction of the state; the state has the discretion to determine the content of education and dissemination through the education of certain philosophical and world outlook ideas; the state is obliged to provide free of charge elementary and general education. Primary education should be compulsory; the obligation of the state is to ensure equal access of persons to education; the obligation of the state is to develop the school system, to establish the optimal system of scholarships, the remuneration of teachers; recognition of a certain degree of educational institutions' autonomy.

Given that research is predominantly based on an analysis of the European Court of Human Rights Practice, the decisions of which are of 
precedent for 47 states, the findings may be of benefit to scientists and civil servants. The main provisions of the study can be used to improve public administration of education, monitor the quality of education, and improve educational legislation.

\section{References}

Al-Shammari ZN, Forlin Ch, Faulkner P. (2019). Theories-based inclusive education practices. Education Quarterly Reviews, 2(2), 408-414. DOI: 10.31014/aior.1993.02.02.73.

Bidjiev D, Borlakova S, Klushina N, Petrova N, Pivnenko P, Uzdenova A, Kharchenko L. (2017). Students' worldview attitude and education content orientation. Journal of History Culture and Art Research, 6(5), 277-284. DOI: http://dx.doi.org/10.7596/taksad.v $6 i 5.1269$.

Claude RP. (2005). The right to education and human rights education. Sur. Revista Internacional de Direitos Humanos, 2(2). http://www.scielo.br/scielo.php?pi $\mathrm{d}=\mathrm{S} 1806$ - 64452005000100003\&script=sci_arttext $\&$ tlng=en.

Convention for the Protection of Human Rights and Fundamental Freedoms. (1950). https://www.echr.coe.int/Docu ments/Convention_ENG.pdf.

Education in Ukraine: Basic indicators. (2018). Information Bulletin. https://mon.gov.ua/storage/app/media/n ova-ukrainska-shkola/1serpkonfinformatsiyniy-byuleten.pdf.

Education Minnesota. (2019). www.educationminnesota.org.

Erçetin ŞŞ, Findık LY. (2016). Chaos, complexity and leadership. In: Springer Proceedings in Complexity, pp. 463475. Luxembourg: Springer. DOI: 10.1007/978-3-319-64554-4_32.

European Court of Human Rights "Case of Altinay v. Turkey", Application No 37222/04.

(2013). http://hudoc.echr.coe.int/fre?i=001122497.

European Court of Human Rights "Case of Appel-Irrgang v. Germany”, Application No 45216/07. (2009). 
http://hudoc.echr.coe.int/eng?i=001112539.

European Court of Human Rights "Case of Çam v. Turkey", Application No 51500/08. (2016).

European Court of Human Rights "Case of Campbell and Cosans v. the United Kingdom", Applications No 7511/76, 7743/76.

http://hudoc.echr.coe.int/eng?i=00157455.

European Court of Human Rights "Case of Costello-Roberts v. the United Kingdom”, Application No 13134/87. (1993). http://hudoc.echr.coe.int/eng?i= 001-57804.

European Court of Human Rights "Case of Folgerø and Others v. Norway", Application No 15472/02. (2007). http://hudoc.echr.coe.int/eng?i=00181356.

European Court of Human Rights "Case of Fredin v. Sweden (No 1)", Application No 12033/86. (1991). http://hudoc.echr.coe.int/eng?i=00157651.
European Court of Human Rights "Case of Kjeldsen, Busk Madsen and Pedersen v. Denmark", Applications No 5095/71; 5920/72; $\quad$ 5926/72.

http://hudoc.echr.coe.int/eng?i=00157509.

European Court of Human Rights "Case of Konrad and Others v. Germany", Application No 35504/03. (2006a). http://hudoc.echr.coe.int/eng?i=00176925.

European Court of Human Rights "Case of Mürsel Eren v. Turkey”, Application No 60856/00. (2006b). http://hudoc.echr.coe.int/eng?i=00172293.

European Court of Human Rights "Case of Lautsi and others v. Italy", Application No 30814/06. (2011). http://hudoc.echr.coe.int/eng?i=001104040.

European Court of Human Rights "Case of Leyla Şahin v. Turkey”, Application No $\quad 44774 / 98$. (2005). http://hudoc.echr.coe.int/eng?i=00170956.

European Court of Human Rights "Case of Marios Georgiou v. Greece", 
Application No 45138/98. (2000). http://hudoc.echr.coe.int/eng?i=001-

5006.

European Court of Human Rights "Case of Sulak v. Turkey", Application No 24515/94. (1996). http://hudoc.echr.coe.int/eng?i=0012669.

European Court of Human Rights "Case of Verein Gemeinsam Lernen", Application No 23419/94. (1995). http://hudoc.echr.coe.int/eng?i=0012278.

European Court of Human Rights "Case Relating to Certain Aspects of the Laws on the Use of Languages in Education in Belgium v. Belgium (Merits)", Applications No 1474/62; 1677/62; $1691 / 62$; 1769/63; 1994/63; 2126/64. (1968). http://hudoc.echr.coe.int/eng?i= 001-57525.

Hou Y, Ni A, Poocharoen O, Yang K, Zhao ZJ. (2010). The case for public administration with a global perspective. Journal of Public Administration Research and Theory, 21(1), i45-i51. DOI: $10.2307 / 40961917$. http://hudoc.echr.coe.int/fre?i=001161149

Iftene C. (2014). Educational systems' autonomy. Facts and analysis. ProcediaSocial and Behavioral Sciences, 142, 47 53. DOI: 10.1016/j.sbspro.2014.07.586. International Covenant on Economic, Social and Cultural Rights. (1966). https://www.ohchr.org/EN/Prof essionalInterest/Pages/CESCR.aspx.

Karahioz RS, Lehka OV, Minchenko SI. (2019). Public administration of legal education in the Practice of the European Court of Human Rights. The Asian International Journal of Life Sciences, 21(2), 493-504.

Kuchuk AM, Serdiuk LM, Zavhorodnia YS. (2019). Modern law education in the context of natural understanding of law. The Asian International Journal of Life Sciences, 21(2), 359-370.

Manan M. (2015). The implementation of the right to education in Indonesia. Indonesia Law Review, 1, 51-68. DOI: 10.15742/ilrev.v5n1.137. 
Markina IA, Chykurkova AD, Dudziak OA, Opaliuk TL, Dobrenko IA. (2019). Globalization-induced changes in higher education management in Ukraine. International Journal of Educational Management, 33(6), 1291-1302. DOI: https://doi.org/10.1108/IJEM-012019-0037.

Mbajiorgu G, Mafumo T. (2014). Striving for quality education: The right to education as a socio-economic right. Mediterranean Journal of Social Sciences, 5(8), 302-311. DOI: 10.5901/mjss.2014.v5n8p302.

Moyaert M. (2018). Inter-worldview education and the re-production of good religion. Education Sciences, 8, 156. DOI: 10.3390/educsci8040156.

Protocol to the Convention for the Protection of Human Rights and Fundamental Freedoms. (1952). https://rm.coe.int/168006377c.

Pysmennyi IV, Lypovska NA. (2015). Ethos of public service in Ukraine: Theoretical and empiric aspects. Public Administration Aspects, 10(24), 5-11. DOI: https://doi.org/10.15421/151577.
Universal Declaration of Human Rights. (1948). Retrieved from:

https://www.un.org/en/universal-

declaration-human-rights/
254 